\title{
Enterobacter aerogenes
}

National Cancer Institute

\section{Source}

National Cancer Institute. Enterobacter aerogenes. NCI Thesaurus. Code C86356.

A species of facultatively anaerobic, Gram negative, rod shaped bacterium in the phylum Proteobacteria. This species is motile, oxidase and indole negative, catalase and citrate positive, ferments lactose and is considered a coliform bacteria. E. aerogenes is found in the gastrointestinal tract and is an opportunistic pathogen commonly acquired nosocomially, causing skin, soft tissue, respiratory, urinary tract and eye infections. 